\section{Review Article}

Check for updates

\title{
Antihypertensive Treatment in Severe Aortic Stenosis
}

\section{Tae Soo Kang, MD, PhD', and Sungha Park, MD, PhD²}

'Division of Cardiology, Dankook University Hospital, Dankook University College of Medicine, Cheonan, Korea ${ }^{2}$ Division of Cardiology, Severance Cardiovascular Hospital, Yonsei University College of Medicine, Seoul, Korea

\section{ABSTRACT}

Previously, antihypertensive treatment in severe aortic stenosis was considered a relative contraindication. However, recent studies have shown that antihypertensive treatment may be safe and even beneficial in terms of reducing the progression of left ventricular pressure overload and even retarding the progression of valvular aortic stenosis. To date, no randomized clinical trials have been performed and no definite treatment guideline exist for the proper antihypertensive regimens. Antihypertensive treatment with $\beta$-blockers has generally been avoided in patients with severe aortic stenosis (AS) due to the concerns for inducing left ventricular dysfunction and hemodynamic compromise in the presence of severe outflow tract obstruction. Although it remains unclear whether antihypertensive treatment with a $\beta$-blocker is associated with increased risk of cardiovascular events in patients with AS, recent studies have shown that the use of $\beta$-blockers may be safe and may even be beneficial. Renin-angiotensin system (RAS) are upregulated in AS and have been shown to be involved in valve calcification and progression in both experimental models and in human trials. As such, theoretically, RAS inhibition would have benefit in retarding the progression of valvular stenosis as well as have benefit in left ventricle remodeling. Recent clinical studies are indeed showing that use of RAS inhibition may be beneficial in patients with AS. Future clinical trials to establish the ideal target blood pressure and antihypertensive regimens in severe AS is essential.

Keywords: Aortic valve stenosis; Antihypertensive treatment; Aortic valve replacement

\section{INTRODUCTION}

The prevalence of calcific aortic valve stenosis (AS), increases with age. ${ }^{12)}$ As such, there are up to $50 \%$ prevalence of hypertension in subjects with AS. ${ }^{3)}$ The presence of hypertension may increase the risk of cardiovascular disease as well as accelerate the progression of aortic stenosis. In the recently published PROGRESSA study, hypertension was shown to accelerate the progression of aortic valve calcification in patients with aortic stenosis. ${ }^{4}$ Also, patients with AS are already burdened by excess pressure overload to the left ventricle (LV) due to the stenotic aortic valve. Hypertension, by increasing the systemic vascular load will add to the already increased after load with subsequent deleterious effect on hypertrophic remodeling LV systolic/diastolic function with subsequent worsening of clinical outcomes ${ }^{577}$ However, antihypertensive treatment in severe AS has been thought of as a relative contraindication due 
to the concern that antihypertensive treatment, due to the presence of fixed obstruction in the aortic valve, may cause excessive peripheral vasodilation and decrease in coronary blood flow, resulting in hypotension and hemodynamic collapse. Recently, studies have shown that these concerns are not supported by clinical practice and that antihypertensive treatment may in fact be needed to improve LV remodeling and ultimately improve the prognosis. Accordingly, recent clinical practice guidelines recommend that hypertension be treated in patients with AS. ${ }^{8)}$

Systemic hypertension aggravates the total $\mathrm{LV}$ pressure overload that is already at a tipping point in patients with severe aortic stenosis. As such, antihypertensive treatment is needed to reduce the LV pressure overload. Antihypertensive treatment with severe AS patients should be started at low doses with careful titration. It should also be emphasized that hypertension can interfere with the accurate assessment of AS severity and that valve and LV hemodynamics should be reevaluated after optimal blood pressure control in hypertensive patients with severe AS.

The main objectives of this review are to briefly review how hypertension adversely affect the progression of AS and review the current evidence regarding the potential benefits of antihypertensive treatment both before and after aortic valve replacement (AVR).

\section{HYPERTENSION AND PROGRESSION OF AORTIC STENOSIS}

Despite the knowledge that hypertension is an important medical problem that requires effective treatment to reduce cardiovascular morbidity and mortality, there has been reluctance to treat hypertension in patients with severe AS.9) The possibility of severe hypotension and hemodynamic collapse with peripheral vasodilation in the setting of a fixed cardiac output was a real concern. Also, there was a concern that the possibility of diastolic hypotension and the subsequent reduction in coronary blood flow will have deleterious effects, especially when considering that many of these patients are predisposed to increased risk of myocardial ischemia under conditions of increased myocardial oxygen demand. ${ }^{10)}$ Recent studies have shown data to refute these old concerns. Hypertension, by increasing the afterload, accelerates the progression of AS and LV hypertrophy and has been shown to be an independent predictor for adverse cardiovascular outcomes. ${ }^{113)}$ In the post hoc analysis from the SEAS trial (Simvastatin and Ezetimibe in Aortic Stenosis), the mortality rate was increased in subjects with asymptomatic AS who had average follow up systolic blood pressure (SBP) of $\geq 160 \mathrm{mmHg}$ with SBP $130-139 \mathrm{mmHg}$ taken as reference. However, there was a J-shaped association between blood pressure and outcomes with blood pressure of 130 to $139 / 70 \mathrm{mmHg}$ being associated with the lowest outcomes. ${ }^{11)}$ This data suggests that although hypertension adversely affects the prognosis of AS, too much lowering (average SBP $<120 \mathrm{mmHg}$ ) may have deleterious effects. Future clinical trials to establish the ideal target $\mathrm{BP}$ in AS is needed.

\section{SAFETY AND POTENTIAL BENEFITS OF RENIN- ANGIOTENSIN SYSTEM INHIBITION IN SEVERE AORTIC STENOSIS}

Renin-angiotensin system (RAS) are upregulated in AS and have been shown to be involved in valve calcification and progression in both experimental models and in human trials. ${ }^{10141415)}$ As 
such, theoretically, RAS inhibition would have benefit in retarding the progression of valvular stenosis as well as have benefit in LV remodeling. Recent clinical studies are indeed showing that use of RAS inhibition may have clinical benefit in patients with severe AS.

In a retrospective analysis of 123 patients who underwent 2 serial electron beam computed tomographic scans, the use of angiotensin converting enzyme (ACE) inhibitors, compared to non ACE inhibitor group, was associated with significant lower rate of aortic valve calcium accumulation. ${ }^{15)}$ In a recent post hoc analysis of the SEAS study, Bang et al ${ }^{16)}$ showed that RAS inhibition was not associated with sudden cardiac death, cardiovascular or all-cause mortality in asymptomatic AS patients. In fact, RAS inhibition was associated with a potentially beneficial effect in blood pressure and reduction in LV mass progression. Several small randomized trials have evaluated the efficacy of RAS inhibition in AS. SCOPE-AS (Symptomatic Cardiac Obstruction-Pilot Study of Enalapril in Aortic Stenosis) randomized 56 patients with symptomatic severe AS to ACE inhibitor. This study demonstrated that enalapril was associated with improvement of the functional class and 6-minute walking distance after 4 and 12 weeks of follow-up. ${ }^{17)}$ Dalsgaard et al. ${ }^{18)}$ randomized 44 patients with severe symptomatic AS referred for AVR to trandolapril. They revealed that the ACE inhibitor group showed significant decreased SBP and increased systemic arterial compliance.

The RIAS trial (Ramipril in Aortic Stenosis) randomized 96 patients with asymptomatic moderate or severe AS with preserved LVEF to either ramipril or placebo. ${ }^{19}$ It showed that ACE inhibition reversed LV hypertrophy ( $p=0.0057)$. Ramipril also had trend to slow the progression of AVA decrease $\left(0.0\right.$ versus $\left.-0.2 \mathrm{~cm}^{2} / \mathrm{y} ; p=0.067\right)$ and the rate of increase in peak velocity $\left(0.03\right.$ versus $\left.0.12 \mathrm{~m} \cdot \mathrm{s}^{-1} \cdot \mathrm{y}^{-1} ; p=0.28\right)$.

With regards to angiotensin receptor blockers (ARBs), there are paucity of data with regards to their efficacy in AS compared to ACE inhibitors. Theoretically, as non ACE pathway such as chymase activation are increased in the aortic valves and angiotensin II type 1 receptors are increased in the aortic valves, ARBs may have benefit comparable to ACE inhibitors in patients with AS with a retrospective study suggesting that ARBs are more effective than ACE inhibitors at reducing aortic valve calcium and $\mathrm{LV}$ remodeling. ${ }^{20}$ However, more data is needed whether or not ARBs have beneficial effects comparable to ACE inhibitors in patients with AS.

Although we will need evidence from larger, randomized outcome studies, recent data suggests the benefit of RAS inhibitors, especially ACE inhibitors in patients with AS. Therefore, ACE inhibitors are likely the preferred agents for treating hypertension with careful titration and dosage to avoid hypotension (Figure 1).

\section{SAFETY AND POTENTIAL BENEFITS OF BETA BLOCKERS IN SEVERE AORTIC STENOSIS}

Antihypertensive treatment with $\beta$-blockers has generally been avoided in patients with severe AS due to the concerns for inducing LV dysfunction in the presence of severe outflow tract obstruction. Although it remains unclear whether antihypertensive treatment with a $\beta$-blocker is associated with increased risk of cardiovascular events in patients with AS, recent studies have shown that the use of $\beta$-blockers are safe and may even be beneficial.

In a post hoc analysis of the SEAS trial, 932 of subjects $(50 \%)$ received beta blockers at baseline. During a median follow up duration of 4 years, $\beta$-blocker was associated with 
Hypertension with severe aortic stenosis

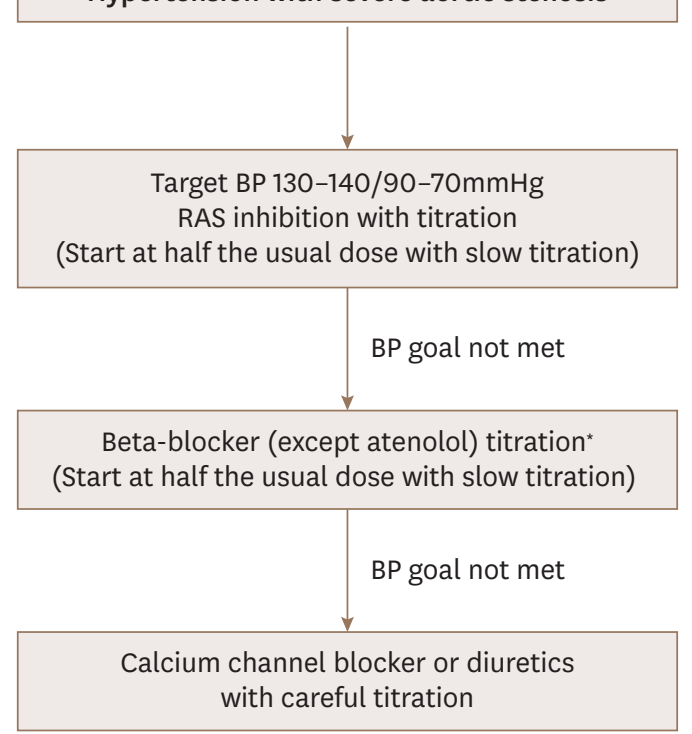

* Contraindication in case of moderate to severe AR combined

Figure 1. Algorithm of antihypertensive treatment of severe aortic stenosis. AR: aortic regurgitation, BP: blood pressure, RAS: renin-angiotensin system.

lower risk of all-cause mortality, cardiovascular death and sudden cardiac death. ${ }^{21)}$ Also, in a retrospective analysis of 113 subjects with symptomatic, severe AS who did not undergo surgery, the use of $\beta$-blocker was associated with $62 \%$ reduction in all-cause mortality. ${ }^{22}$ The benefit of $\beta$-blocker may be due to their potential benefits in terms of reducing hemodynamic and metabolic overload in AS. In a study by Hansson et al. ${ }^{23}$, 40 patients with moderatesevere asymptomatic AS (aortic valve area, $0.5 \pm 0.1 \mathrm{~cm}^{2} / \mathrm{m}^{2}$; peak gradient, $53 \pm 19 \mathrm{mmHg}$ ) were randomized to placebo or metoprolol treatment for 22 weeks. Metoprolol $(100 \pm 53$ $\mathrm{mg} / \mathrm{d}$ ), compared with placebo, significantly decreased the heart rate by -8 beats per minute $(-13,-3 ; p=0.003)$ and increased the systolic ejection time by $26 \mathrm{~ms}(2,50 ; p=0.03)$. Moreover, metoprolol reduced both the aortic valve peak $-7 \mathrm{mmHg}(-13,0 ; p=0.05)$ and mean $-4 \mathrm{mmHg}(-7,-1 ; p=0.03)$ pressure gradients without having any significant effects on stroke volume. The valvuloarterial impedance and myocardial oxygen consumption were reduced by $-11 \%$ and $-12 \%$ ( $p=0.03$ and 0.01 ), respectively. The decrease in heart rate by metoprolol was significantly associated with lower valvuloarterial impedance, myocardial oxygen consumption, and improved myocardial efficiency, defined as stroke work/myocardial oxygen consumption $(\mathrm{r}=0.63-0.65$; all $p<0.01) .{ }^{23)}$ Thus, the results from the above mentioned studies suggest that $\beta$-blockers may have beneficial hemodynamic and metabolic effects and may potentially be favorable in improving the outcome of patients with asymptomatic moderate-severe AS patients (Table 1).

In AS that are associated with significant aortic regurgitation (AR), the use of beta blockers, by increasing the diastolic filling period, potentially increase the severity of the valve regurgitation. As such, the recent 2017 ACC/AHA/ASH hypertension guideline recommends not to use beta blockers in chronic aortic insufficiency. ${ }^{24)}$ Despite these theoretical concerns, there are no evidence that beta blockers are harmful in AR. On the contrary, in a double blind, randomized study in 75 asymptomatic patients with moderate to severe AR, treatment with controlled release metoprolol for 6 months had no significant effect on LV volumes. ${ }^{25}$ ) 
Table 1. Summary of clinical studies of antihypertensive treatment in aortic stenosis

\begin{tabular}{|c|c|c|c|c|c|}
\hline Study & Study type & Study groups & Treatment & Primary endpoints & Other results \\
\hline \multicolumn{6}{|l|}{ RAS inhibitor } \\
\hline \multirow[t]{2}{*}{$\begin{array}{l}\text { SCOPE-AS }{ }^{17)} \\
(2004)\end{array}$} & \multirow[t]{2}{*}{$\begin{array}{l}\text { Randomized } \\
\text { controlled }\end{array}$} & $\begin{array}{l}\text { AVA }<0.75 \mathrm{~cm}^{2}, \text { mean aortic } \\
\text { gradient }>50 \mathrm{mmHg} \text {, or } \\
\text { aortic valve Doppler jet }>4.5 \\
\mathrm{~m} / \mathrm{s} ; \text { NYHA functional class } \\
\geq \mathrm{III} / \mathrm{IV} \text { or angina }\end{array}$ & $\begin{array}{l}\text { Enalapril } 2.5 \mathrm{mg} \\
\qquad(\mathrm{n}=34) \\
\text { vs placebo } \\
(\mathrm{n}=18)\end{array}$ & \multirow[t]{2}{*}{$\begin{array}{l}\text { Enalapril demonstrated significant } \\
\text { improvement in NYHA class, Borg } \\
\text { dyspnea scale }(5.4 \pm 1.2 \text { vs } 5.6 \pm 1.7 \\
p=0.03) \text {, and } 6 \text {-min walk distance } \\
(402 \pm 150 \text { vs } 376 \pm 174, p=0.003)\end{array}$} & \multirow[t]{3}{*}{$\begin{array}{l}\text { Enalapril was tolerated without } \\
\text { hypotension or syncope }\end{array}$} \\
\hline & & 4 weeks follow up & & & \\
\hline $\begin{array}{l}\text { O'Brien } \\
\text { et } \mathrm{al}^{15)} \\
(2005)\end{array}$ & $\begin{array}{l}\text { Retrospective, } \\
\text { observational }\end{array}$ & $\begin{array}{l}80 \text { patients control vs } 43 \\
\text { received ACEI AVC by CT scan } \\
2.5 \text { year interval }\end{array}$ & & $\begin{array}{l}\text { Adjusted odds ratio }(95 \% \mathrm{Cl}) \\
\text { for definite AVC progression was } \\
\text { significantly lower in ACEI group } \\
(0.29 \text { [0.11-0.75], } p=0.01)\end{array}$ & \\
\hline $\begin{array}{l}\text { Capoulade } \\
\left.\text { et } \mathrm{al}^{20}\right) \\
(2013)\end{array}$ & Observational & $\begin{array}{l}\text { Prospectively collected in } \\
338 \text { patients with AS } \\
6.2 \pm 2.4 \text { years follow up }\end{array}$ & $\begin{array}{c}\text { Without } \\
\text { hypertension } \\
\text { (control group), } \\
\text { with hypertension } \\
\text { not treated by RAS } \\
\text { inhibition, treated } \\
\text { with ACEI, ARB }\end{array}$ & $\begin{array}{l}\text { Patients in hypertension group: } \\
\text { faster stenosis progression } \\
\text { ( } p=0.01) \text {, patients on ARBs: slower } \\
\text { AS progression compared with other } \\
\text { groups }\end{array}$ & $\begin{array}{l}\text { Hypertension (HR: } 2.45 ; \\
p=0.006 \text { ) and ACEI (HR: } 2.30 ; \\
p=0.01 \text { ) groups: significant } \\
\text { increase in all-cause mortality } \\
\text { compared with control group }\end{array}$ \\
\hline $\begin{array}{l}\text { Dalsgaard } \\
\text { et } \mathrm{al}^{18)} \\
(2014)\end{array}$ & $\begin{array}{l}\text { Randomized } \\
\text { controlled }\end{array}$ & $\begin{array}{l}\text { Severe symptomatic AS } \\
\text { referred for AVR } \\
\text { For } 3 \text { days }\end{array}$ & $\begin{array}{l}\text { Trandolapril } \\
(\mathrm{n}=22) \\
\text { vs placebo } \\
(\mathrm{n}=22)\end{array}$ & $\begin{array}{l}\text { Significant decrease in systolic BP } \\
\text { and increase in systemic arterial } \\
\text { compliance in ACEI group }\end{array}$ & $\begin{array}{l}\text { No episodes of symptomatic } \\
\text { hypotension. Other hemodynamic } \\
\text { parameters remained unchanged. }\end{array}$ \\
\hline $\begin{array}{l}\text { Bang } \\
\text { et } \mathrm{al}^{16)} \\
(2014)\end{array}$ & $\begin{array}{l}\text { Post hoc } \\
\text { analysis }\end{array}$ & $\begin{array}{l}\left.\mathrm{n}=769 \text { in } \mathrm{SEAS}^{3}\right) \\
\text { AS and preserved LVEF } \\
4.3 \pm 0.9 \text { years follow up }\end{array}$ & RAS inhibitor & $\begin{array}{l}\text { SCD (HR: } 1.19,95 \% \mathrm{Cl}: 0.50-2.83 \text {, } \\
p=0.694), \mathrm{CV}(\mathrm{HR}: 1.05,95 \% \mathrm{Cl}: \\
0.62-1.77, p=0.854) \text { or all-cause } \\
\text { mortality (HR: } 0.81,95 \% \mathrm{Cl}: \\
0.55-1.20, p=0.281)\end{array}$ & $\begin{array}{l}\text { Larger reduction in systolic blood } \\
\text { pressure }(p=0.001) \text { and less } \\
\text { progression of LV mass } \\
(p=0.040)\end{array}$ \\
\hline $\begin{array}{l}\text { RIAS trial }{ }^{19)} \\
(2015)\end{array}$ & $\begin{array}{l}\text { Randomized } \\
\text { controlled }\end{array}$ & $\begin{array}{l}\text { Asymptomatic AS with AVA } \\
<1.5 \mathrm{~cm}^{2} \text { or peak velocity } \\
>3.0 \mathrm{~m} / \mathrm{s} \text { and LVEF }>50 \% \\
1 \text { year follow up }\end{array}$ & $\begin{array}{l}\text { Ramipril } 10 \mathrm{mg} / \mathrm{d} \\
(\mathrm{n}=47) \\
\text { vs placebo } \\
(\mathrm{n}=49)\end{array}$ & $\begin{array}{l}\text { ACEI reversed LV hypertrophy } \\
(p=0.0057) \text {. Slow the progression } \\
\text { of AVA decrease (0.0 vs }-0.2 \mathrm{~cm}^{2} / \mathrm{y} ; \\
p=0.067) \text { and the rate of increase in } \\
\text { peak velocity ( } 0.03 \mathrm{vs} 0.12 \mathrm{~m} \cdot \mathrm{s}^{-1} \cdot \mathrm{y}^{-1} ; \\
p=0.28)\end{array}$ & $\begin{array}{l}\text { There were no differences in } \\
\text { the progression to AVR or major } \\
\text { adverse clinical events between } \\
\text { the two groups }\end{array}$ \\
\hline \multicolumn{6}{|l|}{ Beta blocker } \\
\hline 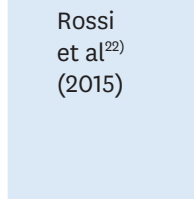 & Retrospective & $\begin{array}{l}\text { Excluded candidate for AVR, } \\
\text { severe AS with symptomatic } \\
\text { EuroSCORE } 30 \pm 20 \\
\text { mean } 10 \pm 10 \text { months }\end{array}$ & BB use vs control & $\begin{array}{l}\text { BB group: lower mortality risk } \\
\text { compared to patients without BBs } \\
\text { (HR: } 0.35,95 \% \mathrm{Cl}: 0.16-0.679 \text {, } \\
p=0.01 \text { ) }\end{array}$ & $\begin{array}{l}\text { Effect of BBs: similar in patients } \\
\text { irrespective of whether they } \\
\text { underwent BAV (HR: } 0.38,95 \% \mathrm{Cl} \text { : } \\
0.13-0.10, p=0.07 \text { ) or not } \\
\text { (HR: } 0.36,95 \% \mathrm{Cl}: 0.10-1.21 \text {, } \\
p=0.09 \text { ) }\end{array}$ \\
\hline $\begin{array}{l}\text { Hansson } \\
\text { et } \mathrm{al}^{23)} \\
(2017)\end{array}$ & $\begin{array}{l}\text { Randomized } \\
\text { controlled }\end{array}$ & $\begin{array}{l}\mathrm{n}=40 \text { moderate-severe } \\
\text { asymptomatic AS } \\
\text { (aortic valve area, } 0.5 \pm 0.1 \\
\mathrm{~cm}^{2} / \mathrm{m}^{2} ; \text { peak gradient, } 53 \pm \\
19 \mathrm{mmHg} \text { ) } \\
22 \text { weeks follow up }\end{array}$ & $\begin{array}{l}\text { Metoprolol } \\
(100 \pm 53 \mathrm{mg} / \mathrm{d}) \\
\text { vs placebo }\end{array}$ & $\begin{array}{l}\text { Metoprolol: heart rate of }-8 \text { beats } \\
\text { per minute }(-13,-3 ; p=0.003) \text {, } \\
\text { increased the systolic ejection time } \\
26 \mathrm{~ms}(2,50 ; p=0.03) \text { and reduced } \\
\text { AV peak }-7 \mathrm{mmHg}(-13,0 ; p=0.05) \\
\text { and mean }-4 \mathrm{mmHg}(-7,-1 ; \\
p=0.03) \text { PG }\end{array}$ & $\begin{array}{l}\text { Valvuloarterial impedance and } \\
\text { myocardial oxygen consumption } \\
\text { were reduced by }-11 \% \text { and }-12 \% \\
(p=0.03 \text { and } 0.01)\end{array}$ \\
\hline $\begin{array}{l}\text { Bang } \\
\text { et } \mathrm{al}^{21)} \\
(2017)\end{array}$ & $\begin{array}{l}\text { Post hoc } \\
\text { analysis }\end{array}$ & $\begin{array}{l}\mathrm{n}=1873 \text { in } \mathrm{SEAS}^{3)} \\
\text { mild to moderate AS and } \\
\text { preserved LVEF } \\
4.3 \pm 0.9 \text { years }\end{array}$ & BB use vs control & $\begin{array}{l}\text { BB: lower risk of all-cause mortality } \\
\text { (HR: } 0.5,95 \% \mathrm{Cl}: 0.3-0.7, p<0.001 \text { ) }\end{array}$ & $\begin{array}{l}\text { CV death (HR: } 0.4,95 \% \mathrm{Cl} \text { : } \\
0.2-0.7, p<0.001) \text {, and SCD } \\
\text { (HR: } 0.2,95 \% \mathrm{Cl}: 0.1-0.6, \\
p=0.004)\end{array}$ \\
\hline
\end{tabular}

ACEI: angiotensin converting enzyme inhibitor, ARB: angiotensin receptor blocker, AS: aortic stenosis, AVA: aortic valve area, AVC: aortic valve calcification, AVR: aortic valve replacement, BAV: balloon aortic valvuloplasty, BB: beta blocker, BP: blood pressure, Cl: confidence interval, CV: cardiovascular, HR: hazard ratio, LVEF: left ventricular ejection fraction, NYHA: New York Heart Association, PG: pressure gradient, RAS: renin angiotensin system, SCD: sudden cardiac death.

Lastly, $\beta$-blocker are the preferred antihypertensive agents in patients with hypertension and thoracic aortic aneurysm, which are frequently associated with AS. ${ }^{24)}$

The above mentioned results suggest that beta blockers may have beneficial hemodynamic effects in AS and may be improve the clinical outcome in patients with severe AS. However, the results should be confirmed in future prospective, randomized trials. 


\section{EFFECT OF VASODILATION ON HEMODYNAMICS IN SEVERE AORTIC STENOSIS}

Vasodilator therapy is a cornerstone in the management of patients with LV dysfunction. However, vasodilators were traditionally contraindicated in patients with severe AS due to concerns that they may precipitate life-threatening hypotension.

However, recent studies have demonstrated the beneficial effects of vasodilatation and afterload reduction in patients with severe AS with heart failure. The Use of Nitroprusside in Left Ventricular Dysfunction and Obstructive Aortic Valve Disease (UNLOAD) Study ${ }^{26)}$ investigated the usefulness of nitroprusside in intensive care unit patients with depressed heart function (ejection fraction $<35 \%$ ), cardiac index $(<2.2 \mathrm{~L} / \mathrm{min}$ per square meter), and severe AS (aortic valve area $<1.0 \mathrm{~cm}^{2}$ ). At baseline, the mean (SD) ejection fraction was $0.21 \pm 0.08$, aortic valve area was $0.6 \pm 0.2 \mathrm{~cm}^{2}$, and peak and mean gradients were $65 \pm 37$ $\mathrm{mmHg}$ and $39 \pm 23 \mathrm{mmHg}$, respectively. After 24 hours of nitroprusside infusion, the cardiac index increased to 2.52 from a baseline of $1.6 \mathrm{~L} / \mathrm{min} / \mathrm{m}^{2}$ with minimal side effect. This study demonstrated that nitroprusside rapidly and markedly improves cardiac function in patients with decompensated heart failure due to severe LV systolic dysfunction and AS and indicates that afterload reduction with arterial vasodilation may improve the hemodynamics of severe AS with reduced ejection fraction with minimal side effects. However, the beneficial effect of after load reduction with RAS inhibitors for a longer duration in severe AS with reduced ejection fraction needs to be confirmed in future clinical trials.

More recently, Eleid et al. ${ }^{27)}$ reported invasive hemodynamic analysis of hypertensive patients with symptomatic low gradient severe AS with preserved ejection fraction who were administered nitroprusside infusion. Nitroprusside infusion was associated with improvement in mean pulmonary artery pressure and LV end diastolic pressure while increasing the aortic valve area and mean pressure gradient. Hypertension is frequently associated with low gradient severe AS and may be a factor to overestimate the severity of the degree of AS. ${ }^{28)}$ Lloyd et al. ${ }^{29)}$ reported that nitroprusside reduces afterload and LV filling pressures in patients with low-gradient severe AS and preserved ejection fraction, enabling reclassification to moderate stenosis in $25 \%$ of patients. Therefore, in asymptomatic low pressure gradient severe AS patients with associated hypertension, initial treatment of hypertension may result in down classification of the severity of the aortic stenosis and allow for medical treatment in some of these patients.

\section{TREATMENT OF HYPERTENSION AFTER AORTIC VALVE REPLACEMENT}

Surgical AVR, including transcatheter aortic valve replacement (TAVR), are the definite treatments of choice for symptomatic severe aortic stenosis. However, technically successful procedure and the associated reduction in the severity of aortic valve obstruction will not automatically guarantee optimal clinical outcomes. Large, randomized trials and registries consistently showed a high rate of readmission despite successful and uncomplicated AVR. ${ }^{30}$ Some data suggest that LV mass regression and abnormal LV and left atrial strain may persist beyond 2 years after AVR and may be related in recurrent episodes of heart failure. ${ }^{30) 31)}$ In an analysis of 105 patients who underwent TAVR, 51\% of the subjects had increase in their blood pressure requiring intensification of antihypertensive treatment. This suggests that effective 
treatment of hypertension may be crucial to optimize the prognosis of patients undergoing surgical or TAVR. ${ }^{32}$

Previous studies have demonstrated that ARB after AVR for severe AS has beneficial effect in terms of reverse remodeling compared to conventional management. In a study by Dahl et al. ${ }^{333}$, 114 subjects who underwent AVR were randomized to either candesartan $32 \mathrm{mg}$ or conventional therapy immediately after surgery. The results showed that mean decrease in LV mass index in the control group was $12 \pm 28 \mathrm{~g} / \mathrm{m}^{2}$ compared to $30 \pm 40 \mathrm{~g} / \mathrm{m}^{2}$ in the candesartan group ( $p=0.015$ ) during follow-up. After 12 months LV mass index was significantly lower in the candesartan group (103 \pm 29 vs $\left.119 \pm 31 \mathrm{~g} / \mathrm{m}^{2}, p=0.01\right)$. In another retrospective observational study, Goel et al. ${ }^{34)}$ analyzed 741 patients who were prescribed RAS inhibitors with 1011 patients who did not receive any RAS inhibitors after surgical AVR between 1991 and 2000 in a single tertiary center. They found that subjects prescribed RAS inhibitors after surgery for at least 6 months were associated with increased survival rates. However, the benefit of RAS inhibitors in hypertensive patients in AS patients after AVR must be confirmed in future clinical outcome studies.

\section{CONCLUSION}

Antihypertensive treatment in severe AS is safe and may be important for reducing the $\mathrm{LV}$ pressure overload and retarding the progression of severe valvular aortic stenosis. To date, no randomized clinical trial has been performed and no definite treatment guideline for antihypertensive regimens. However, RAS inhibitors and $\beta$-blockers are safe may be beneficial in these patients. Based on these observations, we summarized the current available data into a treatment algorithm (Figure 1). Future clinical trials to establish the ideal target BP and antihypertensive regimens in severe AS is essential.

\section{REFERENCES}

1. Mozaffarian D, Benjamin EJ, Go AS, et al.American Heart Association Statistics CommitteeStroke Statistics Subcommittee. Heart disease and stroke statistics-2016 update: a report from the American Heart Association. Circulation 2016;133:e38-360. PUBMED | CROSSREF

2. Nkomo VT, Gardin JM, Skelton TN, Gottdiener JS, Scott CG, Enriquez-Sarano M. Burden of valvular heart diseases: a population-based study. Lancet 2006;368:1005-11. PUBMED | CROSSREF

3. Rosseb $\varnothing \mathrm{AB}$, Pedersen $\mathrm{TR}$, Boman $\mathrm{K}$, et al.SEAS Investigators. Intensive lipid lowering with simvastatin and ezetimibe in aortic stenosis. N Engl J Med 2008;359:1343-56. PUBMED | CROSSREF

4. Tastet L, Capoulade R, Clavel MA, et al. Systolic hypertension and progression of aortic valve calcification in patients with aortic stenosis: results from the PROGRESSA study. Eur Heart J Cardiovasc Imaging 2017;18:70-8. PUBMED | CROSSREF

5. Cramariuc D, Cioffi G, Rieck AE, et al. Low-flow aortic stenosis in asymptomatic patients: valvulararterial impedance and systolic function from the SEAS Substudy. JACC Cardiovasc Imaging 2009;2:390-9. PUBMED | CROSSREF

6. Briand M, Dumesnil JG, Kadem L, et al. Reduced systemic arterial compliance impacts significantly on left ventricular afterload and function in aortic stenosis: implications for diagnosis and treatment. J Am Coll Cardiol 2005;46:291-8. PUBMED | CROSSREF

7. Hachicha Z, Dumesnil JG, Pibarot P. Usefulness of the valvuloarterial impedance to predict adverse outcome in asymptomatic aortic stenosis. J Am Coll Cardiol 2009;54:1003-11.

PUBMED | CROSSREF 
8. Nishimura RA, Otto CM, Bonow RO, et al.ACC/AHA Task Force Members. 2014 AHA/ACC guideline for the management of patients with valvular heart disease: a report of the American College of Cardiology/ American Heart Association Task Force on Practice Guidelines. Circulation 2014;129:e521-643. PUBMED | CROSSREF

9. Lindman BR, Bonow RO, Otto CM. Current management of calcific aortic stenosis. Circ Res 2013;113:223-37. PUBMED | CROSSREF

10. Marquis-Gravel G, Redfors B, Leon MB, Généreux P. Medical treatment of aortic stenosis. Circulation 2016;134:1766-84. PUBMED | CROSSREF

11. Nielsen OW, Sajadieh A, Sabbah M, et al. Assessing optimal blood pressure in patients with asymptomatic aortic valve stenosis: The Simvastatin Ezetimibe in Aortic Stenosis Study (SEAS). Circulation 2016;134:455-68.

PUBMED | CROSSREF

12. Iwata S, Russo C, Jin Z, et al. Higher ambulatory blood pressure is associated with aortic valve calcification in the elderly: a population-based study. Hypertension 2013;61:55-60. PUBMED | CROSSREF

13. Pai RG, Kapoor N, Bansal RC, Varadarajan P. Malignant natural history of asymptomatic severe aortic stenosis: benefit of aortic valve replacement. Ann Thorac Surg 2006;82:2116-22. PUBMED | CROSSREF

14. Ngo DT, Stafford I, Sverdlov AL, et al. Ramipril retards development of aortic valve stenosis in a rabbit model: mechanistic considerations. BrJ Pharmacol 2011;162:722-32. PUBMED | CROSSREF

15. O'Brien KD, Probstfield JL, Caulfield MT, et al. Angiotensin-converting enzyme inhibitors and change in aortic valve calcium. Arch Intern Med 2005;165:858-62. PUBMED | CROSSREF

16. Bang CN, Greve AM, Køber L, et al. Renin-angiotensin system inhibition is not associated with increased sudden cardiac death, cardiovascular mortality or all-cause mortality in patients with aortic stenosis. Int $J$ Cardiol 2014;175:492-8. PUBMED | CROSSREF

17. Chockalingam A, Venkatesan S, Subramaniam T, et al.Symptomatic Cardiac Obstruction-Pilot Study of Enalapril in Aortic Stenosis. Safety and efficacy of angiotensin-converting enzyme inhibitors in symptomatic severe aortic stenosis: Symptomatic Cardiac Obstruction-Pilot Study of Enalapril in Aortic Stenosis (SCOPE-AS). Am Heart J 2004;147:E19. PUBMED | CROSSREF

18. Dalsgaard M, Iversen $\mathrm{K}$, Kjaergaard J, et al. Short-term hemodynamic effect of angiotensin-converting enzyme inhibition in patients with severe aortic stenosis: a placebo-controlled, randomized study. Am Heart J 2014;167:226-34. PUBMED | CROSSREF

19. Bull S, Loudon M, Francis JM, et al. A prospective, double-blind, randomized controlled trial of the angiotensin-converting enzyme inhibitor Ramipril In Aortic Stenosis (RIAS trial). Eur Heart J Cardiovasc Imaging 2015;16:834-41. PUBMED | CROSSREF

20. Capoulade R, Clavel MA, Mathieu P, et al. Impact of hypertension and renin-angiotensin system inhibitors in aortic stenosis. Eur J Clin Invest 2013;43:1262-72. PUBMED | CROSSREF

21. Bang CN, Greve AM, Rosseb $\emptyset \mathrm{AB}$, et al. Antihypertensive treatment with $\beta$-blockade in patients with asymptomatic aortic stenosis and association with cardiovascular events. J Am Heart Assoc 2017;6:e006709. PUBMED | CROSSREF

22. Rossi A, Temporelli PL, Cicoira M, et al. Beta-blockers can improve survival in medically-treated patients with severe symptomatic aortic stenosis. Int J Cardiol 2015;190:15-7. PUBMED | CROSSREF

23. Hansson NH, Sörensen J, Harms HJ, et al. Metoprolol reduces hemodynamic and metabolic overload in asymptomatic aortic valve stenosis patients: a randomized trial. Circ Cardiovasc Imaging 2017;10:e006557. PUBMED | CROSSREF

24. Whelton PK, Carey RM, Aronow WS, et al. 2017 ACC/AHA/AAPA/ABC/ACPM/AGS/APhA/ASH/ASPC/ NMA/PCNA guideline for the prevention, detection, evaluation, and management of high blood pressure in adults: a report of the American College of Cardiology/American Heart Association Task Force on Clinical Practice Guidelines. J Am Coll Cardiol 2018;71:e127-e248.

PUBMED | CROSSREF 
25. Broch K, Urheim S, Lønnebakken MT, et al. Controlled release metoprolol for aortic regurgitation: a randomised clinical trial. Heart 2016;102:191-7.

PUBMED | CROSSREF

26. Khot UN, Novaro GM, Popović ZB, et al. Nitroprusside in critically ill patients with left ventricular dysfunction and aortic stenosis. N Engl J Med 2003;348:1756-63.

PUBMED | CROSSREF

27. Eleid MF, Nishimura RA, Sorajja P, Borlaug BA. Systemic hypertension in low-gradient severe aortic stenosis with preserved ejection fraction. Circulation 2013;128:1349-53.

PUBMED | CROSSREF

28. Little SH, Chan KL, Burwash IG. Impact of blood pressure on the Doppler echocardiographic assessment of severity of aortic stenosis. Heart 2007;93:848-55. PUBMED | CROSSREF

29. Lloyd JW, Nishimura RA, Borlaug BA, Eleid MF. Hemodynamic response to nitroprusside in patients with low-gradient severe aortic stenosis and preserved ejection fraction. J Am Coll Cardiol 2017;70:1339-48. PUBMED | CROSSREF

30. Mack MJ, Leon MB, Smith CR, et al.PARTNER 1 trial investigators. 5-year outcomes of transcatheter aortic valve replacement or surgical aortic valve replacement for high surgical risk patients with aortic stenosis (PARTNER 1): a randomised controlled trial. Lancet 2015;385:2477-84. PUBMED | CROSSREF

31. Douglas PS, Hahn RT, Pibarot P, et al. Hemodynamic outcomes of transcatheter aortic valve replacement and medical management in severe, inoperable aortic stenosis: a longitudinal echocardiographic study of cohort B of the PARTNER trial. J Am Soc Echocardiogr 2015;28:210-217.e1-9. PUBMED | CROSSREF

32. Perlman GY, Loncar S, Pollak A, et al. Post-procedural hypertension following transcatheter aortic valve implantation: incidence and clinical significance. JACC Cardiovasc Interv 2013;6:472-8. PUBMED | CROSSREF

33. Dahl JS, Videbaek L, Poulsen MK, et al. Effect of candesartan treatment on left ventricular remodeling after aortic valve replacement for aortic stenosis. Am J Cardiol 2010;106:713-9. PUBMED | CROSSREF

34. Goel SS, Aksoy O, Gupta S, et al. Renin-angiotensin system blockade therapy after surgical aortic valve replacement for severe aortic stenosis: a cohort study. Ann Intern Med 2014;161:699-710. PUBMED | CROSSREF 